\title{
PENSANDO NOS VALORES MORAIS: CASAMENTO CIVIL E DIVÓRCIO EM BELÉM (1890/1900) ${ }^{1}$
}

\author{
Ipojucan Dias CAMPOS \\ Universidade do Estado do Pará \\ ipojucan@ hotmail.com
}

Resumo: O propósito deste artigo é o de compreender como o decreto ${ }^{\circ} 181$ de 24 de janeiro de 1890 que secularizou tanto o casamento quanto a separação conjugal (divórcio) foi interpretado na cidade de Belém entre 1890 e 1900. A referida lei foi razão de muita tensão e intriga que envolveu diversas Instituições e segmentos sociais como a Igreja Católica e o Estado Republicano bem como jornalistas, juristas e cônjuges. Desta maneira, no texto que segue foi crucial colocar em evidência os inúmeros discursos desses segmentos os quais divergiam, mas também convergiam a todo o momento em uma cidade que se mostrava preocupada com as inserções que o poder secular promovia em assuntos que há séculos se encontravam sob o domínio do Clero.

Palavras-chave: Belém. Casamento Civil. Divórcio. Igreja Católica. República.

Abstract: The purpose of this article is it of understanding as the ordinance no. 181 of January 24, 1890 that secularized as much the marriage as the matrimonial separation (divorce) it was interpreted in the city of Belém between 1890 and 1900. Referred her law reason of a lot of tension and intrigue that it involved several Institutions and social segments as the Catholic Church and the Republican State was as well as journalists, jurists and spouses. Of this it sorts things out, in the text that proceeds it was crucial to put in evidence the countless speeches of those segments which diverged, but they also converged the all the moment in a city that was shown concerned with the inserts that the secular power promoted in subjects that there are centuries they were under the domain of the Clergy.

Keywords: Belém. Civil Marriage. Divorce. Catholic Church. Republic.

\section{Introdução}

O decreto do casamento civil, impio, iniquo, immoral e vexatorio, é uma violencia á consciencia dos brazileiros e um attentado enorme contra os sagrados direitos da Igreja catholica (Semana Religiosa do Pará. Belém, 13 de abril de 1890, p. 234).

A secularização do casamento e do divórcio ${ }^{2}$ foi realizada pela República por meio do decreto $\mathrm{n}^{\mathrm{o}} 181$ de 24 de janeiro de 1890; antes desse período a Igreja Católica era a única

\footnotetext{
${ }^{1}$ Este artigo é inteiramente dedicado à memória de Maria do Socorro Dias da Silva. O texto que segue é uma síntese do item 1 do capítulo 2 de minha dissertação de mestrado intitulada "Casamento, divórcio e meretrício em Belém no final do século XIX (1890/1900)" defendida em outubro de 2004 na Pontifícia Universidade Católica de São Paulo (PUC/SP) sob a orientação da professora doutora Estefânia Knotz Canguçu Fraga.

${ }^{2}$ A forma de divórcio que entraria em vigor no Brasil, em 24 de maio de 1890, por meio do decreto ${ }^{\circ}$ 181, não conferia aos interessados a possibilidade de ruptura matrimonial, inexistindo assim segundas núpcias em vida de um ou outro cônjuge. Desta maneira, o instituto se reduzia a "simples" separação de corpos e bens. Outro esclarecimento necessário concentra-se na terminologia divórcio: esta foi utilizada da Colônia ao primeiro Código Civil Brasileiro aprovado em 1916 e o seu uso justifica-se porque inexistia no direito de então uma terminologia que melhor explicasse as separações de corpos e bens, visto que o termo desquite foi introduzido no direito brasileiro somente a partir do referido Código Civil.
} 
Instituição que possuía o poder de casar e de separar legalmente no país. ${ }^{3}$ Desse modo, pensar a Belle-Époque belenense a partir dessa legislação numa cidade que se modernizava e se ampliava geograficamente e que ao mesmo tempo guardava valores e costumes conservadores, é o eixo central deste artigo.

Sobre o casamento civil e o divórcio, 1890 foi um ano de muitas polêmicas no interior da sociedade brasileira. Em Belém, para este estudo, os debates revelam-se como densos e ocuparam espaços significativos em vários periódicos que circulavam na cidade naquele período. Densos, porque as discussões envolveram não apenas os casamentos civil e religioso e o divórcio, mas também a família, a moral e a norma. Não obstante, neste momento, necessário se faz lembrar que o referido decreto-lei permitia aos cônjuges quatro possibilidades legais de se divorciar: "adultério de qualquer um dos cônjuges, sevícias e injúrias, abandono voluntário do lar por um ou outro dos consortes, se prolongado por dois anos contínuos, e o livre consenso dos parceiros (o divórcio amigável) desde que casados fossem há mais de dois anos" (BEVILAQUA, 1896).

Desta maneira, é frugal afirmar que as análises seguintes serão sustentas por meio de determinados jurisconsultos como Clovis Bevilaqua com a obra Direito da família e Lafayette Rodrigues Pereira com Direito de família, um processo de divórcio que foi utilizado para explicar que o pensado pela Igreja e outros setores conservadores da sociedade em nenhum momento conseguiu alcançar a todos e inúmeras folhas que foram publicadas na Belém oitocentista que contemplaram as supracitadas temáticas: O Diário do Grão Pará, $O$ Apologista Cristão Brasileiro, Semana Religiosa do Pará, Diário de Notícias e O Democrata. Neste recorte cronológico, estes periódicos deram de várias formas - cada um à sua maneira atenção às formas de matrimônios e ao divórcio. Cada um ao seu modo porque, a partir das leituras e interpretações feitas, constatou-se que alguns jornais procuravam etiquetar o casamento civil e o divórcio com palavras acabrunhantes (desagregadores das relações familiares, gangrenas sociais e morais, trarão a proliferação de filhos ilegítimos, corroboram para a disseminação da prostituição). Tais adjetivações procuravam, assim, desqualificar o enlace civil frente ao religioso católico e refutar as separações de corpos e bens.

\footnotetext{
3 Por um curto período, no Império, o casamento civil foi transformado em lei. Após longas discussões parlamentares a proposta do Ministro Francisco Vasconcellos transformou-se na lei $\mathrm{n}^{\mathbf{o}} 1144$ em setembro de 1861 e regulamentada com o Decreto $\mathrm{n}^{\mathrm{o}} 3069$ em abril de 1863. A nova possibilidade matrimonial desagradou aos setores mais conservadores da sociedade, dentre os quais a Igreja Católica. Em 1865 já não era possível realizar conúbio civil no país, ou seja, extinguia-se esse modelo de celebração em virtude de pressões eclesiásticas.
} 
Enfim, mesmo o conúbio civil e o divórcio sofrendo críticas de variados segmentos da sociedade belenense, os dois institutos se faziam presentes na cidade.

Seguem-se, então, as reflexões.

\section{Casamento civil e divórcio: escalas de poder na cidade oitocentista}

Sobre a epígrafe o especialista das letras jornalísticas compreendia o casamento civil como um atentado à moralidade. Com as letras impressas na revista Semana Religiosa do Pará ficam expressos que os posicionamentos do periódico eram repulsivos a tal conúbio, isto é, a referida revista considerava a nova forma matrimonial uma instituição irreligiosa e injusta, uma vez que, para o periódico, ele não convergia às veleidades da sociedade brasileira, além de ferir os sagrados direitos da Igreja Católica. Direitos que certamente eram o da exclusividade da celebração do casamento, o qual os católicos nunca entenderam como um contrato, mas como um sacramento indissolúvel.

A Semana Religiosa do Pará expressou o sentido do casamento civil. No entanto é incoerente perder de vista que o periódico colocava-se ao lado da Igreja posicionando-se contrário diante do enlace civil e do divórcio. Passando em revista a alguns editoriais do periódico, encontraram-se discussões sobre as temáticas em análise. Nas interpretações dos documentos, percebe-se que as discussões sobre o decreto 181 de 24 de janeiro de 1890 foram objetos de muitas contestações na impressa de Belém. Os articulistas desta folha deixavam claro que existiam concepções diversas de casamento. O Apostólico Católico Romano tinha o sentido de sacramento, sendo que o outro, o civil, se encerrava como um simples concubinato e feria os sagrados direitos da Igreja catholica. O Clero compreendia que somente uma das formas de enlace era legítima e salubre, ou seja, apenas o casamento realizado pelos seus ministros apreendia-se válido. O conúbio civil para a Igreja tinha o sentido de contrato inexistindo legitimidade religiosa; por conseguinte, dava-se o enlace cartorial como um concubinato; um amasiamento; uma mancebia.

Por seu turno, o divórcio concentrava-se em um processo incompreensível para uma parte da sociedade belenense, já que se enxergava em tal instituto uma acentuada incompatibilidade com a família, com a moral pública e privada e ainda com o poder de desarmonizar a vida doméstica. As razões apresentadas contra os processos de divórcio mostravam-se variadas, dentre as quais a possibilidade da desmoralização do casamento. Civilmente, mesmo com a República transformando, com o decreto-lei o casamento civil e o 
divórcio num ato de responsabilidade do poder secular, o regime republicano não rompeu com o ideal da indissolubilidade matrimonial. (CAMPOS, 2004). Percebe-se, assim, que a lógica de família pensada tanto pelo poder eclesiástico quanto pelo secular se aproximava. Tal ideal passava necessariamente pelo paradigma da indissolubilidade dos vínculos e pela noção monogâmica e a do instituto representar a higienização no bojo da sociedade. O mínimo que é válido supor é que o novo regime de governo em muito se encontrava envolto com os referenciais religiosos católicos. Dessa forma, apreende-se o porquê do referido decreto-lei ter perpetuado o mesmo sentido e ideal de família que há séculos a Igreja Católica tinha a exclusividade de formar por meio dos seus referenciais. A projeção do que viria a ser uma união válida e conseqüentemente de família legítima saiu, com as leis republicanas, do raio de influência da Igreja Católica; contudo, o casamento civil deve ser percebido como o término da exclusividade católica, porém jamais como o início de um novo ideal. Segundo Keila Grinberg, mesmo com as pressões políticas e religiosas impingidas pela Igreja Católica contra a secularização tanto do divórcio quanto do casamento, o decreto de 24 de janeiro de 1890 deu como terminada a exclusividade do Clero sobre estes institutos. (GRINBERG, 2001).

As redes de relações de poder e de interesses eram múltiplas e se delongavam no país. Sobre o decreto 181, a sua análise leva a perceber que a História se estabelece num campo de possibilidades, tanto para o lado daqueles que se posicionavam contrários àquela forma de casamento quanto para os favoráveis a ele. As teias de poder sobre este instituto tornam-se exemplares quando para impedir qualquer ação da Igreja, o Governo promulgou o decreto de 26 de junho de 1890, este surgiu como um dispositivo que tornava obrigatória primeiro a celebração do enlace civil para que, depois, se celebrasse o religioso. Veja-se o que expressava o artigo $2^{\circ}$ do decreto 318: "O ministro de qualquer confissão, que celebrar as cerimonias religiosas do casamento antes do acto civil, sera punido com seis meses de prisão e multa correspondente á metade do tempo". ${ }^{4}$

O Governo Provisório justificava para estabelecer o decreto que:

ao principio de tolerancia consagrado no decreto $n^{\circ} 181$ de 24 de janeiro ultimo, que permite indifferentemente a celebração de quesquer cerimonias religiosas antes ou depois do acto civil, tem correspondido uma parte do clero catholico com actos de accentuada opposição e resistencia á execução do mesmo decreto, celebrando o casamento religioso e aconselhando a não observância da prescripção civil.

Que, por este modo, não só se pretende annular a aç̧ão do poder secular, pelo desrespeito aos decretos e resoluções, como ainda se põe em risco os

\footnotetext{
${ }^{4}$ Decretos do governo provisório da República dos Estados Unidos do Brasil de 1890. Sexto fascículo de 1 a 30 de junho de 1890. Rio de Janeiro: Typ. da Imprensa Nacional, 1890.
} 
mais importantes direitos da família, como são aquelles que resultam do casamento $[\ldots] .5$

As escalas de força eram grandes entre a República e a Igreja Católica, ainda que o ideal de casamento convergisse para um centro comum: o monogâmico-indissolúvel. Com o referido decreto, as leis republicanas consolidaram as suas pretensões, ou seja, "que o casamento, em virtude das relações de direito que estabelece, é celebrado sob a protecção da Republica". 6 A este respeito, Rosa Maria Barboza de Araújo observou que as leis republicanas estabeleceram que era o casamento civil o único que poderia legitimar a família (ARAÚJO, 1993). Para inviabilizar ainda mais qualquer resposta da Igreja, o Governo

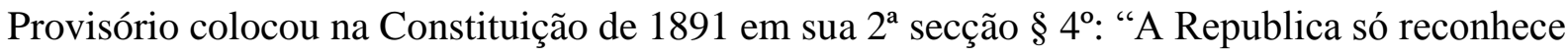
o casamento civil, que precederá sempre a cerimônia religiosa de qualquer culto". Desta maneira, pouco era interesse das duas Instituições colocarem em linha de análise novos vínculos afetivos. A Instituição que celebraria o casamento válido no Brasil mudava, no entanto, as funções do matrimônio permaneciam as mesmas (CAMPOS, 2004).

As alianças interessavam tanto a República quanto o Clero. Este, com a perda do monopólio da celebração do casamento monogâmico legal, nunca se sentiu confortável frente às celebrações cartoriais; afirmava que o decreto-lei estava sendo repelido e publicava que "a lei não seria executada sem violências". Por seu turno, o periódico "O Apologista Cristão Brasileiro" em uma de suas matérias que viera a público com uma chamada em letras garrafais "VIOLÊNCIAS ... DE QUEM?" refutava a resistência da Igreja Católica. Para endereçar as críticas, o jornal copilou uma matéria editada por um dos periódicos da Igreja Católica:

Casamento Civil. - Cartas do interior do Maranhão e do Piauhy, de pessoas respeitaveis, nos asseguram que o decreto sobre o casamento civil tem sido geralmente repellido, e suppõe-se que semelhante lei não será executada sem violencias. ${ }^{7}$

Contrapondo-se a esse editorial encontrava-se o adversário da Igreja não unicamente na imprensa paraense, mas também no conjunto social e político: O Apologista Cristão Brasileiro. Este se apresentava sempre muito loquaz quando se direcionava à Santa Sé, além de se referir com desprezo ao que era publicado pelos veículos da Cúria Romana em relação as núpcias cartoriais.

\footnotetext{
${ }^{5}$ Decretos do governo provisório da República dos Estados Unidos do Brasil de 1890. Sexto fascículo de 1 a 30 de junho de 1890. Rio de Janeiro: Typ. da Imprensa Nacional, 1890.

${ }^{6}$ Idem.

${ }^{7}$ Semana Religiosa do Pará. Belém, 02 de março de 1890. Apud: O Apologista Cristão Brasileiro de 08 de março de 1890, p. 01.
} 
Desejamos muito saber de que maneira e em que occasião e por quem e porque motivo.

Não podemos imaginar um caso do casamento civil ao qual a propria canalha podia se oppôr. Ninguém se casa, não querendo. Todos podem casar-se na igreja romana querendo. Os que assim se casam poderão deixar de casar-se civilmente, assim querendo. Ninguem os obriga a casar-se civilmente. A lei simplesmente declara que em tal caso não são casados.

Os que se vão casar civilmente irão por que querem. Não são elles que hão de praticar as 'violencias'. Casando-se, não offendem a ninguem: quem e quando é que vão praticar ás 'violencias'?."

$\mathrm{Na}$ interpretação desta fonte percebe-se que havia, por parte do periódico, olhares proibitivos e ao mesmo tempo a presença de críticas frente aos posicionamentos da Igreja Universal sobre o enlace civil. Num primeiro momento, a referida folha teceu refutações em relação às ameaças de violência que foram propagandeadas pela Igreja Católica. O Apologista Cristão Brasileiro argumentava perguntando de modo crítico em quais ocasiões? Por quem? E por quais motivos seriam praticadas as violências? O desejo do matutino com estas indagações era o de promover um enfrentamento com a Cúria Romana. Em suas articulações seguintes, notam-se ironias diante dos atos defendidos nos domínios católicos. A matéria discorria que qualquer pessoa poderia se casar nos templos católicos e que ninguém estava impedindo ou procurando impedir essa possibilidade, sendo que aqueles que desejassem tais núpcias poderiam negar o casamento civil, no entanto, as leis brasileiras apenas os considerariam como não casados. O semanário tecia comentários irônicos sobre as possíveis práticas de violência indagando num segundo momento: "quem e quando é que vão praticar ás 'violencias'?". Interpretando este documento, sente-se que as intrigas que se formaram entre a Igreja Católica e os Protestantes Metodistas de Belém mostravam-se grandes ou, melhor dito: estes, com a mais leve discordância acerca das posturas tomadas pelos Apostólicos Romanos, teciam críticas de relevo sobre os seus posicionamentos. Deste modo, suas opiniões sobre as alianças civis e o divórcio, em nenhum momento foram convergentes.

Os domínios - "sociedade dita moralmente correta" com casamento civil e o divórcio - eram irreconciliáveis para a Igreja Católica de Belém do final do século XIX. Esta impossibilidade era corriqueiramente publicada pela imprensa católica, por exemplo, uma matéria publicada em a Semana Religiosa do Pará que teve como chamada: A Igreja e o Estado. As palavras da revista narravam:

[...] Ahi vem, com effeito, o casamento civil, contrario á doutrina da Igreja, enchendo a nação de uniões illicitas.

\footnotetext{
${ }^{8}$ O Apologista Cristão Brasileiro. Belém, 08 de março de 1890, p. 01.
} 
Ahi vem o divorcio legal, consequencia fatal do casamento civil, desunindo as famílias com um simples processo lavrado por um escrivão do foro [...]. ${ }^{9}$

O documento expõe à sociedade belenense que o casamento civil mostrava-se um instituto que conduziria a uniões ilícitas. Sutilmente o articulista da revista corroborava para a idéia de que o matrimônio religioso católico deveria ser mantido como o formador da família legalmente constituída. Examinando-se a documentação, percebe-se que se procurava dar importância ao sacramento católico ficando, assim, o enlace civil em segundo plano, visto que a matéria deixa supor que a única núpcia válida seria aquela celebrada pela Igreja Católica. Desta maneira, percebia-se o casamento laico como não formador da família legal. $\mathrm{O}$ documento tecia críticas ao decreto que seria promulgado pelo governo republicano provisório; conseqüentemente algumas novas reflexões vêm à tona, dentre as quais a relação entre alianças civis e a sua maior propensão para o divórcio, isto é, o documento sugeria e procurava relacionar o matrimônio cartorial como sinônimo de divórcio, pois a Igreja propagandeava que a união feita diante do foro civil durava pouco, levando à separação conjugal.

Outra ilação possível de se observar é como a folha procurou refutar a construção de uma semelhança entre o matrimônio e um simples contrato. As linhas impressas pelo periódico indicam que foi o governo republicano, por meio do decreto-lei de 24 de janeiro de 1890, que procurou tecer a idéia de que os enlaces matrimoniais se encerravam simplesmente em contratos. Esta articulação, até onde é possível perceber, foi rechaçada pela Igreja Católica, ou seja, a Instituição compreendia que o matrimônio se encerrava em uma determinada categoria e o contrato, em outra. Os dois institutos, para a Igreja Apostólica, se repeliam mutuamente, uma vez que o enlace matrimonial era indissolúvel e o contrato poderia ser desfeito em qualquer ocasião, articulava-se. O jurista Lafayette Rodrigues Pereira, na obra Direito de família, discorreu de forma bastante parecida quando analisou as temáticas divórcio, matrimônio e contrato. Em seu trabalho, observou o casamento como substrato da ordem social familiar, destarte, as transformações não poderiam acontecer na ordem daqueles que advogavam o divórcio e o casamento cartorial. O instituto em sua visão consolidava o bem estar moral e social e não poderia ser visto como um simples contrato e sim como uma relação especial que se formava perpetuamente entre os nubentes (PEREIRA, 1889).

A partir das análises dos documentos é perceptível apreender que os jogos de força que se estabeleceram entre a Igreja e a República foram avolumados, pois que as duas

\footnotetext{
${ }^{9}$ Semana Religiosa do Pará. Belém, 19 de janeiro de 1890, pp. 33, 34, 35, 36 e 37.
} 
Instâncias divergiam frente a temáticas como o divórcio e o casamento civil; no entanto, no jogo de divergências, houve convergências que se devem acentuar. Clero e República confluíam para a indissolubilidade matrimonial e tinham o mesmo ideal de família: $a$ monogâmica-higiênica. Neste sentido, as divergências sobre estas temáticas davam-se no campo de como seria formada a pilastra desta família monogâmica e do casamento indissolúvel, isto é, se das bases religiosas ou do poder secular republicano. Esta se mostrava ser a principal problemática em questão entre os campos religioso e laico. Apreende-se que estavam estabelecidos jogos de política bastante intensos entre as duas instâncias de poder, pois a Igreja não desejava perder a sua exclusividade sobre a formação da família legítima e para isso se articulava por meio dos periódicos. Por seu turno, a República estabeleceu a secularização do casamento possibilitando o matrimônio civil.

O Diário do Grão Pará com uma matéria intitulada Casamento obrigatório em 11 de março de 1890, disparava de forma sutil contra a República. A matéria narrava que "o regime republicano ganharia, além de fazer um enorme favor perante a sociedade si deixasse de lado a lei do casamento civil, este sangra os interesses nacionaes". ${ }^{10}$ Quando a Igreja Católica percebeu que revogar o decreto-lei $\mathrm{n}^{\mathrm{o}} 181$ era improvável passou, sutilmente, a atacar o regime republicano. No documento acima, a folha utilizava argumentações para tentar fazer com que o casamento laico não fosse homologado pelo regime. Neste documento, a Santa Sé procurou expor que as núpcias perante uma autoridade civil em nada contemplavam os interesses da nação. O matutino afirmava que os republicanos fariam um favor para o conjunto da sociedade se desistissem de promulgar a lei que estabelecia o enlace civil. $\mathrm{O}$ Clero procurava mostrar a inviabilidade deste modelo de casamento que tantas outras vezes havia sido inviabilizado por força de sua influência no bojo das relações sociais. A partir dos argumentos acima, é possível vislumbrar que a secular Cúria colocava-se totalmente desfavorável ao instituto, uma vez que ela afirmava que este enlace sangrava os interesses nacionais. Destarte, relendo com atenção os argumentos apresentados pela folha, infere-se que a Igreja Católica jamais desejou sujeitar o matrimônio às leis civis do país, no entanto, o instituto, a cada dia, tendia a se transformar num ato laico.

Do assunto a Igreja Católica tratava com certo desconforto, mas procurava conjugar esforços no sentido de desqualificar o enlace cartorial. Portanto, o casamento religioso era visto por ela como uma forma de honrar a Deus publicamente. Por seu turno, o casamento cartorial - com o objetivo de procurar conservar seus interesses - a Santa Sé o considerava

${ }^{10}$ O Diário do Grão Pará. Belém, 11 de março de 1890, p. 02. 
como emancipação da referida honra pública. Quando se celebrava o casamento civil ou decretava-se uma sentença favorável de divórcio a moral em muito edificada somente pelo matrimônio religioso, transformava-se em espectro no interior da sociedade, pensava a Igreja Católica. Mas esses discursos não conseguiam alcançar a todos, por exemplo, o casamento, que começou a se desfazer legalmente por meio de uma ação de divórcio nos corredores do Tribunal de Justiça do Estado do Pará em 09 de maio de 1900, entre a impetrante Justiniana Rosa das Chagas Nunes e Libanio Antonio Nunes, pode ajudar nestas reflexões. Eles receberam as bênções núpciais diante dos ministros Católicos na paróquia da Sé "aos vinte e seis dias do mez de Outubro do anno de Mil oitocentos e setenta e sete". Vinte e três anos o matrimônio havia. Em 09 de maio de 1900, iniciava-se o auto de divórcio no Tribunal de Justiça que teve como demandante dona Justiniana. Alegava-se como razão para o divórcio o $\S 3^{\circ}$ do decreto $n^{\circ} 181$ de 24 de janeiro de 1890: "abandono voluntario do domicilio conjugal e prolongado por dois annos continuos”. Há sinalizações no libelo de que já por alguns anos, no seio familiar, vinham se prolongando determinadas tensões conjugais. No Tribunal de Justiça do Estado do Pará, a autora afirmava que mesmo a sua vida se confundindo com a de seu marido, o convívio sob um mesmo teto era impossível em decorrência dos "maus tratos" que Libanio the infligia cotidianamente. ${ }^{11}$ Argüia-se em juízo que a princípio a suplicante “[...] tolerou com resignação esses maus tratos, porem como elles continuassem e de dia para dia mais se accentuasse o genio rixoso de seu marido, foram finalmente obrigados a separarse, datando esta separação de alguns annos".

Por meio do depoimento da testemunha Antonio Manoel do Nascimento de 48 anos, solteiro, artista, foi publicizado que a separação entre os consortes perfazia cerca de três anos. Isto é, no libelo do processo a possível abandonada acusava o esposo de ter desamparado as relações familiares e conseqüentemente o lar conjugal por mais de dois anos contínuos e que em nada contribuía para a manutenção sua e de seus filhos Manoel, Firmina e Genezio. As conjugações acusatórias pesavam. Centraram-se as acusações no pouco provimento do lar doméstico e nas práticas seviciosas do réu. Em decorrência do abandono, dona Justiniana argüia que foi obrigada à "penosa contingencia de trabalhar para prover á alimentação propria e de seus filhos". Sendo demandante de um processo de divórcio, no qual acusava o esposo de abandono do lar e conseqüentemente também de ser pouco provedor, e de ter ido ao mercado de trabalho para conseguir sustentar a si e a seus filhos são indicativos expressivos de que o projeto pensado e pretendido às mulheres pelo Estado e Igreja foi diversas vezes questionado

${ }^{11}$ Ação de divórcio litigiosa impetrada por Justiniana Rosa das Chagas Nunes contra Libanio Antonio Nunes, 1900. 
por elas. O recato, a submissão e a candidez foram normas sociais que sofriam reelaborações pelos impetrantes dos autos de divórcio. (SAMARA, 1989).

Nota-se que mesmo os valores e costumes das elites e da Igreja Católica se fazendo sentir em diversos espaços da Belle-Époque, a cidade não pode ser apreendida como homogênea. Nela houve tensões que foram impossíveis de se tolherem. Isso acontece porque as pessoas possuem papéis sociais que se concentram em padrões e normas de comportamento exigidas para e por aqueles que ocupavam determinadas posições nas escalas de poder.

Na busca dos vestígios deixados pelos periódicos sobre as suas apreensões acerca do casamento civil e do divórcio dar-se-á voz a folha $O$ Democrata, pois, o periódico fornece outras referências sobre tais assuntos. Este jornal em uma das suas publicações trazia como chamada: A institucionalização da devacidão:

A Republica teria tudo a ganhar se desistisse de ferir de frente as tradições veneradas do povo, seus costumes, direitos adquiridos. Se desistisse de decretar a lei do casamento civil e do divorcio, estes tem um unico fim: corromper as tradições familiares nacionaes. ${ }^{12}$

A manchete desta matéria expressa muitos significados, entre os quais o de convocar os seus leitores a uma rejeição aos dois institutos que se avizinhavam. Para consolidar a sua posição, utilizou a palavra "povo", que poderia representar, no contexto em que foi escrita, significados variados, pois que o jornalista expressava que o divórcio e o casamento civil iam de encontro às tradições supostamente veneradas pelo povo e encerrava o primeiro período proferindo que o decreto-lei feria os direitos que foram adquiridos pela população. As latentes pluralidades estavam cintilando. Adotando-se outros termos, nesta publicação vislumbram-se os planos e os contra-planos contidos no conteúdo da informação publicada, isto é, o veículo não criticava apenas o divórcio e o casamento civil que poderiam, segundo a folha, desestruturar a ordem familiar. Os críticos argumentos giravam também em torno do novo regime de governo estabelecido. Para conseguir maior ressonância contra a República foi utilizado, nas linhas do documento, um antigo mas eficaz argumento: a família. Era prática comum no seio da imprensa paraense e nos processos de divórcio da última década do século XIX, utilizar, para se contrapor aos decretos do governo provisório, a família, a prole, a moralidade pública e privada e a ordem. Estas preocupações, que muitas vezes se revelaram no cerne das discussões dos jornais de Belém, fazem presumir que a família tinha uma representação significativa no interior da dinâmica social da cidade. Chegou-se a esta suposição a partir do momento em que foram percebidas sutilezas: [..] corromper as tradições

\footnotetext{
12 O Democrata. Belém, 13 de março de 1890, p. 03.
} 
familiares nacionaes". Dessa forma, a referida matéria usava um significativo jogo de palavras ao tentar passar aos seus destinatários a idéia de que os dois institutos exerciam uma força degenerante sobre a família.

Esta conjectura acerca dos posicionamentos de determinadas folhas publicadas na Belém do século XIX tomou uma maior musculatura quando se analisou a matéria que $O$ Democrata intitulou M. Gladstone e o divorcio, publicada em março de 1890. O jornal:

M. Gladstone acaba de publicar no Nort American Review de New York, um importante e notavel artigo sobre o divorcio.

A força de uma sociedade estando baseada sobre a familia e a solidez da familia dependendo do casamento, Gladstone não admite o divorcio, no sentido em que se attribue á palavra: admite sómente em certos casos graves e condicionalmente o que se poderia chamar separação de corpos, separação que não pode nem annular o casamento, nem dispensar os casados de suas obrigações.

Declara em seguida que casamento de pessoas divorciadas não é admissivel em caso algum, e estabelece os principios seguintes:

$O$ casamento é essencialmente um contrato por toda a vida; o casamento christão encerra um voto feito á Deus; nenhuma autoridade foi concedida á Egreja para rescindir esse voto; não depende tão pouco do poder civil, que póde prohibil-o, mas não annulal-o depois de feito, o casamento dos divorciados é prohibido pelas escripturas sagradas; as leis da Egreja Latina e tambem da anglicana não permittem o casamento de pessoas divorciadas; o divorcio altera profundamente o caracter do casamento, não repousa sobre base alguma de principio ou de autoridade e nunca existiu nos tempos primitivos. Enfim, denota uma decadencia e a força em augmento do imperio das paixões. ${ }^{13}$

Oferecem-se vestígios expressivos para se tecer suposições acerca das bases em que se encerravam os seus posicionamentos sobre o casamento, a família e o divórcio. A análise da matéria permite perceber, a partir de algumas palavras que a tecem, que o referido periódico concordava com a linha de raciocínio de Gladstone, isto é, quando a folha afirmava que um determinado sujeito social publicou na revista norte-americana Nort American Review de Nova Iorque um "importante e notavel artigo sobre o divorcio" faz-se preciso atentar a essas adjetivações e aos seus significados. As palavras "importante e notável” possuem sentidos bastantes nobilizadores se comparadas com as discussões que vinha sendo travadas no interior dos jornais paraenses sobre aquele contexto histórico do final do século XIX. Desse modo, a partir de vestígios que foram deixados na matéria jornalística, é possível sentir que a linha editorial de $O$ Democrata comungava com os postulados forjados por Gladstone. O diário era adverso às separações conjugais e ao casamento cartorial.

${ }^{13}$ O Democrata. Belém, $1^{\text {o }}$ de março de 1890, p. 02. 
A folha, ao que tudo indica, coligiu o texto publicado por Gladstone na Nort American Review e não construiu oposição à matéria que primeiramente foi publicada nos Estados Unidos. Esta inrelutância, num primeiro plano, tenha sido porque o escrito contemplava as sensibilidades da linha editorial do periódico, porquanto a matéria inteira reafirmava a importância da família, do casamento e negava a necessidade do divórcio vincular. O ministro Gladstone se contrapunha ao divórcio a vínculo; no entanto, considerava admissível o divórcio sem ruptura dos vínculos matrimoniais. O ministro, discorrendo sobre as temáticas, dava vigor aos debates que se estavam realizando por uma parte expressiva da imprensa paraense, pois novamente convergiam aos posicionamentos dos jornais O Diário do Grão Pará e O Democrata. Posicionamentos, aliás, muito difundidos, de que o conúbio não poderia ser apreendido como um contrato qualquer, mas sim instituto indissolúvel que, uma vez celebrado entre os nubentes, não poderia ser desfeito visto que tinha sido selado um voto na presença de Deus. Ficava clara a visão do matrimônio como sacramento e em nenhuma hipótese como vínculo que poderia ser desfeito conforme os interesses dos cônjuges. Neste eixo, indissolubilidade e sacramento eram dois institutos que a matéria deixava evidente que nenhum poder, nem o da Igreja e nem tampouco o do Estado, tinha como desfazer. ${ }^{14}$

A partir da análise dessas questões é possível perceber as imagens que cintilavam quando o assunto concentrava-se em matrimônio e divórcio. O matrimônio, para uma parte da sociedade bellepoqueana, jamais se encerrou num contrato comum que fosse possível desatar ao mais leve movimento das vontades porque a sua causa, o seu objeto, a sua duração, os seus efeitos, nunca foram os mesmos quando comparados a outros, uma vez que era vislumbrado como o meio organizador da família legítima. Esta, por seu turno, assentava em bases sólidas a sociedade civil, pensava-se.

\section{Considerações finais}

Uma das pretensões do Estado Republicano, da Igreja Católica, de juristas, de jornalistas era a de emoldurar, tanto o matrimônio como o divórcio, em determinados referenciais que nada se constituíam em análogos. Quanto ao matrimônio, interpretava-se ser um instituto higiênico, salubre, perene, enfim o principal sustentáculo dos vínculos familiares. Em relação ao divórcio, os ditos representantes da moral tentavam caracterizá-lo como ato

\footnotetext{
${ }^{14}$ O jornal "Diário de Notícias" publicado em 02 de março de 1890 também publicou e comentou a mesma matéria que Gladstone realizando comentários similares aos do periódico "O Democrata". Ver: "Diário de Notícias". Belém, 02 de março de 1890, p. 03.
} 
que tinha a força de desestruturar as higiênicas relações concebidas no interior do enlace conjugal. Os articulistas das matérias que utilizaram sobejamente Gladstone expunham que o relaxamento dos laços da vida conjugal e familiar eram os responsáveis pelo amortecimento da moralidade.

Grosso modo, por tudo que foi dito parte da sociedade de Belém negava a possibilidade de dissolubilidade dos vínculos matrimoniais, noção bastante enraizada nas linhas editoriais dos jornais, nas concepções da Igreja e nas da República. Para estes, as discussões sobre o divórcio e do casamento civil tinham de levar em consideração as razões da moralidade, porquanto se compreendia constituir-se grande erro pretender reduzir a matéria do casamento e do divórcio a uma simples questão jurídica; mostrava-se necessário levar, em linha de conta, as razões da moralidade pública e privada. Esta possibilidade ficou mais inteligível quando os periódicos tomaram emprestadas as palavras de Gladstone: "Depois desta época a moralidade tem diminuido nas mais elevadas classes e todos reconhecem que se tem relaxado muito os laços da vida conjugal e da família". ${ }^{15}$

Nota-se que nos interstícios dos debates frente ao casamento civil e o divórcio há inteligivelmente a linha da moral, da ética e da normatização das pessoas. Por envolver o direito de família, esta temática despertou muitos interesses. Se por um lado, o Clero no Brasil parece ter saído "arranhado", pois nunca conseguiu anular o decreto que laicizou o casamento e o divórcio, atos que definitivamente mantiveram-se sob a responsabilidade da República. Por outro, a sua influência foi expressiva na formulação de tal decreto-lei, uma vez que o divórcio perpétuo com possibilidades de segundas núpcias em vida do outro cônjuge não foi admitido. O máximo que as leis republicanas estabeleceram foi a separação permitida pelo Direito Canônico, ou melhor dito, aquele que proporcionava apenas a separação de corpos e bens (LOPES, 2002).

A partir da interpretação dos documentos ficou verossímil que havia em suas linhas a predominância de termos como corromper a prole, corromper as tradições familiares nacionais, desestruturação familiar e indissolubilidade do matrimônio. Essas foram as etiquetas, bordões e adjetivações prediletas utilizadas por aqueles que compreendiam que se divorciar e celebrar conúbio civil rompiam com os costumes e valores que há muito estavam estabelecidos no seio da sociedade belenense. Mas é necessário ressaltar que as escalas de poder no interior da sociedade em momento algum funcionavam apenas tomando como parâmetros os valores e costumes que há séculos estavam estabelecidos, mas também pelas

\footnotetext{
${ }^{15}$ Diário de Noticias. Belém, 02 de março de 1890, p. 03.
} 
relações sociais e pelos intercâmbios cotidianamente urdidos por mulheres e homens que preferiram o litígio bem como a celebração cartorial. Em conformidade com isso, os vínculos de poder, neste período, não devem ser entendidos como uma via de mão única, ou seja, apenas a partir daqueles que discordavam com as ações de divórcio ou com o casamento civil, esta trama em nada era isenta de clivagens, tensões e contradições internas. Elas de maneira nenhuma se desenrolaram numa polaridade, visto que mulheres e homens divorciados eram donos de campos de força bastante significativos, onde se vislumbravam interesses e perspectivas divergentes.

Exemplo neste sentido foi os protestantes (aqui se refere aos Metodistas de Belém) que se interessavam pelas mudanças que o governo provisório estava promovendo no interior da vida civil brasileira. Vislumbravam-se espaços mais amplos para a exposição de suas idéias, uma vez que, com o estabelecimento do civil, o religioso católico deixava de ser a forma de matrimônio válido. Enfim, os interesses de ambas as partes estavam em campos diametralmente opostos, sendo que uma delas - os católicos - sentia que as suas vantagens estavam ameaçadas, e a outra - os Protestantes Metodistas - buscava assegurar as suas.

Os conflitos e confusões disso resultantes foram complexos e significativos para a sociedade belenense. Os códigos sociais que prevaleciam naquele momento frente ao conúbio eram diferentes para as duas Instituições religiosas: católica e metodista. Também nesta linha de raciocínio é possível ver que a cidade de Belém em nada se mostrava única. Com efeito, a Belle-Époque não pode ser compreendida como um espaço citadino monolítico, onde imperavam, de modo absoluto, as concepções da Igreja Católica como se as suas aspirações contrárias ao casamento civil e ao divórcio fossem ouvidas e ecoadas de modo equânime no conjunto da sociedade.

Outros espaços, noções e posicionamentos houve e neles se conseguiram perceber diversas imagens em relação às temáticas estudadas.

\section{Documentos}

\section{Processo de divórcio}

Ação de divórcio litigiosa impetrada por Justiniana Rosa das Chagas Nunes contra Libanio Antonio Nunes, 1900.

\section{Periódicos e legislação}

Diário de Notícias, 1890. 
O Diário do Grão Pará, 1890.

O Apologista Cristão Brasileiro, 1890.

O Democrata, 1890.

Semana Religiosa do Pará, 1890.

"Capítulo VII: Dos efeitos do casamento". In: Decreto do governo provisório da República dos Estados Unidos dos Brasil. Primeiro fascículo de 1 a 31 de janeiro de 1890. Rio de Janeiro: Typ. da Imprensa Nacional, 1890.

“Capítulo IX: do divórcio". In: Decreto do governo provisório da República dos Estados Unidos dos Brasil. Primeiro fascículo de 01 a 31 de janeiro de 1890. Rio de Janeiro: Typ. da Imprensa Nacional, 1890.

Decretos do governo provisório da República dos Estados Unidos do Brasil de 1890. Sexto fascículo de 1 a 30 de junho de 1890. Rio de Janeiro: Typ. da Imprensa Nacional, 1890.

\section{Referências}

ARAÚJO, Rosa Maria Barboza de. A Vocação do Prazer: a cidade e a família no Rio de Janeiro republicano. Rio de Janeiro: Rocco, 1993.

BEVILAQUA, Clovis. Direito da Família. Recife: Ramiro M. Costa Editores, 1896.

CAMPOS, Ipojucan Dias. Casamento, divórcio e meretrício em Belém no final do século XIX (1890/1900). Dissertação apresentada na Pontifícia Universidade Católica de São Paulo (PUC/SP). São Paulo: Mimeo, 2004.

CANCELA, Cristina Donza. Casamento e Relações Familiares na Economia da Borracha (Belém 1870/1920). Tese apresentada na Faculdade de Filosofia, Letras e Ciências Humanas (FFLCH/USP). São Paulo: Mimeo, 2006.

GRINBERG, Keila. Código Civil e Cidadania. Rio de Janeiro: Jorge Zahar, 2001.

LOPES, Cristiane Fernandes. Quod Deus conjuxit homo non separet: um estudo de gênero, família e trabalho através das ações de divórcio e desquite no Tribunal de Justiça de Campinas (1890/1934). Dissertação de mestrado apresentada na Faculdade de Filosofia, Letras e Ciências Humanas (FFLCH/USP). São Paulo: Mimeo, 2002.

PEREIRA, Lafayette Rodrigues. Direito de Família. Rio de Janeiro: Typ. da Tribuna Liberal, 1889.

SAMARA, Eni de Mesquita. As mulheres, o Poder e a Família: São Paulo, século XIX. São Paulo: Marco Zero, 1989. 